\title{
Is Microfinance Beneficial or Opportunistic?
}

\author{
Kaniz Habiba Afrin, Atia Ahmed \\ Varendra University, Rajshahi, Bangladesh
}

\begin{abstract}
Microfinance has been established targeting access to finance for poor people who are screened out from getting loans from formal financial institutions due to lack of collateral and low creditworthiness. There has undergone a tremendous transformation in all aspects of microfinance, including outreach and portfolio size, proliferation of microfinance through a large number of microfinance institutions, diversification of services, new regulatory regime, contribution in rural development, recognition of microfinance as a major contributor in poverty reduction, etc. However, the microfinance sector is facing many challenges regarding institutional capacity, quality, and diversity of services, fallout from political and macroeconomic factors, replication of agricultural credit, and so forth. The objective of this article is to find out whether microfinance has impact on poverty reduction and economic development at all.
\end{abstract}

Keywords: microfinance, NBFI, collateral, poverty reduction, non-financial services

\section{Introduction}

Microfinance has been described as a root program and strategy for poverty reduction and local, economic, and social development of third world countries for the last few decades. Microfinance institutions (MFIs) serve a large percentage of low-income pastoral families in many developing countries. There are a large number of microcredit projects that are in process around the world. International donors, lending agencies, and general governments allot billions of dollars for microcredit programs. As the outreach of microfinance is increasing all over the world, the hopes created in the world that microfinance will lead to a poverty free world. Microfinance does not only cover financial services but also non-financial assistance such as training and business advice.

Bangladesh is the motherland of microfinance. There are more than one thousand microfinance institutions in Bangladesh. The outreach of microfinance institutions is also great. So this is expected that microfinance has a large contribution in the poverty reduction in Bangladesh. In Bangladesh, microcredit has reached more than 60 percent of its poor (World Bank, 2008).

The microfinance movement began in Bangladesh with the work of Nobel Laureate Dr. Muhammad Yunus in the late 1970s, spreading rapidly to other developing countries. Most early microfinance institutions (MFIs), including Yunus’s own iconic Grameen Bank, relied on funding from government and international donors, justified by MFI claims that they were reducing poverty, unemployment, and deprivation. The model of the Grameen Bank of Bangladesh is the most well-known and discussed model.

Kaniz Habiba Afrin, assistant professor, Department of Business Administration, Varendra University, Rajshahi, Bangladesh. Atia Ahmed, assistant professor, Department of Business Administration, Varendra University, Rajshahi, Bangladesh.

Correspondence concerning this article should be addressed to Kaniz Habiba Afrin, Department of Business Administration, Varendra University, Rajshahi 6204, Bangladesh. 


\section{Objectives and Questions}

The major objective of the study is to find out whether microfinance has impact on poverty reduction and economic development in developing and underdeveloped countries or whether it is opportunistically benefitting itself in the name poverty alleviation.

\section{Primary or Focused Questions}

(1) What is the role of microfinance in poverty reduction?

(2) What is the role and importance of microfinance in social development?

(3) What is the focus of microfinance on?

\section{Related Questions}

(1) Does micro-credit reach the poorest?

(2) Does microfinance contribute to enterprise growth and income?

(3) Is microfinance an effective strategy to reach the Millennium Development Goals (MDGs)?

(4) Does microfinance promote economic growth and development?

(5) Why has microfinance not worked as hoped?

(6) Is microfinance sustainable?

(7) What is the link between microfinance institutions and poverty alleviation?

\section{Literature Review}

Microfinance gives access to financial and non-financial services to low-income people, who wish to access money for starting or developing an income generation activity. The individual loans and savings of the poor clients are small. Microfinance came into being from the appreciation that micro-entrepreneurs and some poorer clients can be bankable, that is, they can repay, both the principal and interest, on time and also make savings; provided financial services are tailored to suit their needs. Microfinance as a discipline has created financial products and services that together have enabled low-income people to become clients of a banking intermediary.

Microfinance affects household welfare in many areas. The evaluation focused on five primary areas: (i) income, expenditure, and savings; (ii) other financial transactions; (iii) household enterprise and employment; (iv) household assets; and (v) human capital investments. The review is organized around these areas. Since microfinance in general and the project being evaluated in particular focus on the impact on poor households, the review also covers the outreach of microfinance on poor households.

A couple of reviews of studies dealing with the impact of microfinance have been conducted recently. These reviews highlight the disagreement in the results. Much of the disagreement emanates from the different degrees with which earlier studies have controlled for problems that are now acknowledged to significantly affect impact assessments—nonrandom program participation, nonrandom program placement, and nonrandom dropout (Cull, Demirgüç-Kunt, \& Morduch, 2007).

Weiss, Montgomery, and Kurmanalieva (2003) reviewed the evidence of the microfinance impact on poverty in Asia and subsequently. Weiss and Montgomery (2005) provided an update including studies using Latin American data. They reviewed only more "rigorous studies" and have not covered studies using qualitative or participatory approaches. Weiss and Montgomery (2005) summarized their review by saying that 
The conclusion from the early literature, that whilst microfinance clearly may have had positive impacts on poverty it is unlikely to be a simple panacea for reaching the core poor, remains broadly valid. Reaching the core poor is difficult and some of the reasons that made them difficult to reach with conventional financial instruments mean that they may also be high risk and therefore unattractive microfinance clients.

A similar conclusion was also arrived at by an earlier review in Zeller and Meyer (2002). Surveying available evidence for Asian countries, they concluded that while there seems to be overall positive effects on income and education, results differ substantially across countries and programs both in magnitude as well as statistical significance and robustness. In many studies we have seen different concept and controversy on the contribution of microfinance institution. Aneel Karnani, an associate professor of strategy at the University of Michigan’s Ross School of Business, points out:

Microloans are more beneficial to borrowers living above the poverty line than to borrowers living below the poverty line. This is because clients with more income are willing to take the risks, such as investing in new technologies that will most likely increase income flows. Poor borrowers, on the other hand, tend to take out conservative loans that protect their subsistence, and rarely invest in new technology, fixed capital, or the hiring of labor.

Microloans sometimes even reduce cash flow to the poorest of the poor, observed by Vijay Mahajan, the chief executive of Basic, an Indian rural finance institution. He concludes that "Microcredit seems to do more harm than good to the poorest” .

One reason could be the high interest rates charged by microcredit organizations. Acleda, a Cambodian commercial bank specializing in microcredit, charges interest rates of about 2 percent to 4.5 percent each month. Some other micro lenders charge more, pushing most annual rates to between $30 \%$ and $60 \%$. Microcredit proponents argue that these rates, although high, are still well below those charged by informal money lenders. But if poor clients cannot earn a greater return on their investment than the interest they must pay, they will become poorer as a result of microcredit, not wealthier. The fact is, most microcredit clients are not micro entrepreneurs by choice. They would gladly take a factory job at reasonable wages if it were available. We should not romanticize the idea of the "poor as entrepreneurs". It has been said that all economic growth has its origin in saving. Someone has to save, in order to give someone else the opportunity to loan. The economist Milton Friedman has said that "The poor are left in poverty, not because they are lazy, but because they lack access to capital”.

One of the critical factors that prevent development in almost all poor countries is that the poor are excluded from financial services. Access to financial, such as savings, credit, insurance, and money transfer, contributes to expanding the individual's choices and ability to respond to opportunities. Their vulnerability is reduced when meaning that smooth consumption and bridges crises are provided. These kinds of services are rarely accessible through the formal financial sector. Banks generally assume that it is unprofitable to provide small loans and deposits, and therefore avoid the poor as clients. It is believed that the cost and risk of delivering small-scale financial services at the local level is too high for non-subsidized institutions and that the informal financial market meets the demand. Credit is widely available from informal commercial money lenders, but usually at a very high cost to the borrower. Informal commercial lenders often charge a nominal effective interest rate of $10 \%$ to $100 \%$ a month (Robinson, 2001, pp. 15-17).

The International Labor Organization (ILO) uses a more appropriate term for these people: "own-account workers". Creating opportunities for steady employment at reasonable wages is the best way to take people out of poverty. The ILO states: "Nothing is more fundamental to poverty reduction than employment". 


\section{MFIs in Bangladesh}

Microfinance in Bangladesh got tremendous popularity over the last more than three decades starting from the pioneering work the Grameen Bank. Bangladesh, with a population of more than 140 million, is one of the most densely populated countries (1,061 persons per square kilometer) in the world. Poverty is pervasive here. Almost half of the total population is still living below the poverty line-earning less than $\$ 1$ a day. The various dimensions of the country's poverty are manifested in terms of inequality in income distribution (in favor of urban areas), wage differentials between the formal and informal sectors, dramatic increases in the cost of living, less than adequate calorie intake by the vast majority of the population, unemployment, and internal migration. The government of Bangladesh faces an enormous challenge in reducing poverty. However, the government cannot act alone as it cannot command all the resources, personnel, administrative outreach or expertise necessary to maintain progress in poverty alleviation. The MFIs have taken a key role in poverty alleviation efforts and they have been providing credit to these poor people who lack savings and capital but want jobs in the farm and non-farm sectors. There are more than one thousand MFIs in Bangladesh now. The major MFIs are Grameen Bank, Bangladesh Rural Advancement Committee (BRAC), Association for Social Advancement (ASA), Palli Karma-Sahayak Foundation (PKSF), Padakhep Manobik Unnayan Kendra (PMUK), Proshika, etc. The case of microfinance, Bangladesh is a good example of non-government organization led operations where the government directly and indirectly provided major policy and material support to make it probably the largest microfinance sector in the world.

\section{MFIs Products and Product Diversification}

A lot of financial products are offered by microfinance institutions. The microcredit program in Bangladesh rightly began by targeting the rural poor especially women as a development intervention strategy. Microcredit serves not only to meet financial needs but also contributes to other social and institutional development issues such as women's empowerment, bringing the rural poor into an institutional service network and reducing the dependency on informal money lenders. The management system of micro-finance programs has evolved over time but commonly has the following features:

- Women are the main recipients of microfinance services though many MFIs now have male members or clients.

- Group-based lending methodology is the main system of delivery of microfinance services, although commercial banks and a number of MFIs offer loans to individual clients.

- The microfinance sector in Bangladesh is now dominated by Non-Governmental Organizations (NGOs) offering microfinance services, collectively known as NGO-MFIs which offer financial services as "private not-for-profit businesses” but strive to achieve institutional and financial viability as soon as possible.

- MFIs are diversifying into other target segments, including near-poor groups, by developing new financial products along with the traditional management system.

- Loans are collateral free but to ensure repayment poor women are organized into groups to take responsibility of repayment.

- Loans are small that is manageable by the poor and repayments are also small collected in weekly installments.

- Instead of coming to the bank the approach takes financial service at the door of the poor; bank's staff members collect supervise and take care of all management tasks similar to any commercial bank. 
- Procedures for loan applications and other administrative steps have been simplified to suit the poor.

- All financial transactions are made in public to eliminate any possibility of corruption or political intervention.

- Experience shows that loan money is normally invested in commonly available activities such as livestock rearing, trading, agriculture production, and small processing operations.

In addition to mainstream microcredit, other products include savings product, services for the poor, microenterprise credit, seasonal loan, micro-insurance, extreme poor products, conditional cash transfer, education loan, health \& housing loan, training \& skill development programs, etc.

\section{Interest Rate Structure of MFI Products}

The interest rates charged on credit products as well as that provided to savings products by major MFIs of Bangladesh are as follows:

Table 1

Interest Rate Structure of MFI Products

\begin{tabular}{llll}
\hline Organizations & Interest on credit (flat) & $\begin{array}{l}\text { Effective interest } \\
\text { rate on credit products }\end{array}$ & Interest on savings \\
\hline ASA & 14.4 & 28.8 & Less than $5 \%$ \\
BRAC & 15 & 30 & Regular savings: 8.5 \\
Grameen Bank & 10 & 20 & Time deposits: 12.5 \\
PKSF Funded MFIs & Hardcore poor: 10 & Hardcore poor: 20 & 4 \\
Other MFIs & Others: 12.5 & Others: 25 & 5.5 \\
IBBL-RDS & 15 & 30 & 15 \\
\hline
\end{tabular}

\section{Challenges for the MFIs}

Bangladesh microfinance sector now has passed beyond doubt the era where studies were conducted to prove its effectiveness but now faces new challenges of other emerging issues. In order to make the microcredit programs effective for poverty reduction, the government emphasized small entrepreneurship. It also identified the following challenges:

(1) Prevalence of high interest rates are being reduced, but further reduction of interest rate is necessary;

(2) Vicious cycle of microcredit follows, where the poor are borrowing from one microcredit organization to repay another;

(3) Microcredit programs have not been very successful in including the hardcore poor;

(4) Rate of graduation to above the poverty line among the microcredit borrowers is low, indicating persistent dependency on microcredit;

(5) Most of the microcredit recipients are women; they bear the increased burden of repayment;

(6) Microcredit organizations compete with each other and often put pressure on the potential clients to borrow;

(7) The profitability of micro enterprises is small and often is not sustainable on a long-term basis because of enterprise decapitalization, saturation of markets for products that are traditionally produced by microcredit borrowers, weak coordination among NGOs and MFIs, and a weak financial system. 


\section{The Link Between Microfinance and Poverty Alleviation}

Since its inception, microfinance has evolved as an economic development approach to benefit low-income people in rural and urban areas. Poverty alleviation or reduction is an ultimate goal of most MFIs, with either direct or indirect links to immediate objectives.

Since mid-1980s, a large number of studies have been conducted on the impact of microfinance program on poverty. The studies find that microfinance program has benefited the poor in more than one way. The program has improved their living standard through diversification, strengthening of their survival strategies, improving their security, providing access to assets and rights and increasing their self-respect, giving them choices and independence. The access to microfinancial services has enabled the poor to undertake diversified economic activities, which generate flow of income year round and thus strengthen the survival strategy of the poor. Without microfinancial services, security for the poor rural households would come from patron-client and mutual sharing and borrowing arrangements, which have weakened over the years.

With microfinancial services, the poor households now own and command assets and savings which they can cash or use to meet contingencies without sacrificing their independence, security or peace of mind, by getting into debt. Microcredit borrowers, for example, were able to face the devastating floods of 1998 using their assets and savings. Microcredit borrowers can now depend substantially on their own assets and reserves to meet contingencies and do not have to depend on borrowings from patrons or moneylenders with conditions that had included usurious rates of interests, meeting obligations like free labor, supporting patrons in unjust local feuds and elections, etc. There is self-respect among the borrowers, which had previously been absent. Microfinance program has also empowered its beneficiaries and raised their social and political consciousness which is reflected, among others, in their increased participation in local government, national elections, and social mobilization and activities like building community roads, running health programs and community schools.

However, the fact that all the microfinance institutions are working for the poor is not always true. In most cases, it has been seen that the microfinance institutions are doing their businesses with the poor, and poverty alleviation is their nominal policy to expand their businesses. In some cases, it has been also observed that the poor have become poorer with microcredit due to high interest charge as well as high pressure of early loan payment. Again it has been noticed that some microfinance institutions did not give loans to the rootless on their belief, rather they would give loans only to these who had the capability to repay the loans. That is, they would provide loans to those who had collaterals indirectly, not to those who would have been made able to repay the loans by utilizing their skills.

So, side by side with beneficial activities, there are some negative aspects of microfinance that cause the rootless poor not only to lose their present conditions but also to lose their ability to work in an effective and efficient manner.

\section{The Link Between Microfinance and Social Impact}

Although MFIs' initial objective was not primarily in the social realm, if at all, most MFIs do now identify one or more social goals: women's empowerment, children's school attendance, awareness of and demand for health services, etc. Evidence of the social impact of microfinance in Bangladesh has also been mixed, but again, on balance, suggests that microfinance and the associated activities of MFIs have had positive social effects. Indeed, it often seems as if this fundamentally economic approach has performed best in the social 
domain. Khandker (2005, p. 266) notes that the earlier World Bank (WB)/Bangladesh Institute of Development Studies) (BIDS) supports the claim that microfinance programs promote investment in human capital (such as schooling) and raise awareness of reproductive health issues (such as the use of contraceptives) among poor families., and that microfinance helps women exercise power in household decision-making.

It is widely recognized that access to credit can often foster social, psychological, and even political empowerment. Credit services for the poor and particularly poor women, reverse their systemic exclusion from access to public or private funds, thus altering systems of hierarchy and power (see, for example, Todd, 1996). Access to alternative means of finance can reduce dependency on moneylenders and those who lend money; at the same time, access to institutional credit also can be used as a bargaining chip in order to secure informal loans. In general, a leveling of the playing field occurs, allowing the poor to participate more effectively in the social, economic, and political workings of their community.

However, it should be noted that finance alone did not lead to such changes but other developmental and macro-factors have definitely contributed positively or negatively. On the whole the researches have proved the positive impacts of financial services for the poor. Bangladesh microfinance sector now has passed beyond doubt the era where studies were conducted to prove its effectiveness but now faces new challenges of other emerging issues such as continued vulnerability of poor due to external factors, overlapping of microcredit services, impact on microfinance in an era of slow or no growth of economy, and lack of new and more demand-driven products, etc.

\section{Focus of the MFIs}

Apparently, the main focus of the MFIs is on how to alleviate poverty. Most of the MFIs are working with the slogan of poverty alleviation. However, a deeper look into the operation of most MFIs shows us that in the name of poverty alleviation, some MFIs are conducting their profitable businesses. Their clients are the rural, rootless poor who cannot but go to them for microfinance because these people have no access to traditional banking institutions without collaterals. In a sense, they are compelled to apply for the microcredit to the MFIs. And with this opportunity, the MFIs try their best to utilize their resources to the best available sources. In brief, we can say that these MFIs are doing their businesses but fortunately they are helping the rootless people. That is, some MFIs are not based on the objectives to alleviate poverty, but poverty is being alleviated through their activities. So, the behavior of these MFIs is opportunistic, rather than beneficial.

\section{Overall Analysis of the Role of Microfinance}

Today the role of MFIs is controversial for many reasons. Despite the slogan of "credit for the poorest of the poor", the poorest have not fully benefited from the microfinance revolution of late 1990s in Bangladesh. We now examine the overall impacts of microfinance in the following aspects:

\section{Does Microcredit Reach the Poorest?}

Currently microfinance institutions can provide a small percentage of poor people. We have seen many people are not well known of their services. So, a small percentage of people are able to generate their income. A large percentage of people excluded from their services.

In case of Bangladesh, we have seen a little hope regarding this issue. Grameen Bank and BRAC make a positive impact in case of this issue. One study showed that program participants are able to raise $5 \%$ of their expense. Extreme poverty among BRAC household also reduces from $20 \%$ to $14 \%$. 
Table 2

Penetration Ratio That Microfinance Provides

\begin{tabular}{|c|c|c|c|c|c|}
\hline Rank & Country name & Total borrowers & Number of MFI's & $\begin{array}{l}\text { Average amount } \\
\text { borrowed }\end{array}$ & Penetration ratio \\
\hline 1 & Bangladesh & $24,000,000$ & 70 & 350,000 & $35 \%$ \\
\hline 2 & India & $10,700,000$ & 106 & 100,000 & $3 \%$ \\
\hline 3 & Vietnam & $5,800,000$ & 12 & 500,000 & $11 \%$ \\
\hline 4 & Indonesia & $3,800,000$ & 42 & 900,000 & $25 \%$ \\
\hline 5 & Mexico & $3,300,000$ & 40 & 850,000 & $14 \%$ \\
\hline
\end{tabular}

Does Microfinance Contribute to Enterprise Growth and Income?

Storey (1994) notes that policy-makers should consider the dangers associated with the very high failure rates for microenterprises, particularly new start-ups. For example, in Tamil Nadu State in India, one program study found less than $2 \%$ of microenterprises still operating three years after their establishment (George, 2005). In Bosnia and Herzegovina, World Bank researchers found that up to $50 \%$ of microenterprises failed within one year of their establishment (Cull, Demirgüç-Kunt, \& Morduch, 2007). As Davis, Hands, and Maki (2007) note from their work on Bangladesh, such failure can lead to irretrievable poverty.

Generally, the reason behind this failure is: At a primary stage the growth and income of a enterprise is very low, which does not cover their own need as well as the high interest rate of microfinance institution.

But it is true that microcredit is very effective for an established enterprise. An established enterprise can successfully utilize this microcredit to generate their growth and income.

\section{Is Microfinance an Effective Strategy to Reach the MDG?}

No single intervention can defeat poverty. Microfinance is not a panacea for poverty and related development challenges, but rather an important tool in the mission of poverty eradication. In many ways MFIs are helping to reach the MDG. MDGs generally focused on the health care, nutrition, education, environmental improvement, unexpected mortality of children and mother, etc. All of these factors can be established successfully when households have increased earnings and greater control over financial services. And the earnings of household can be increased through the effective mechanism of microfinance institutions.

\section{Does Microfinance Promote Economic Growth and Development?}

Lack of access to credit markets is a major reason why many economies cannot develop. In Latin America, over 360 million people lack access to basic financial institutions. Financial technologies like credit, investment, savings accounts, and insurance are important because they are a form of investment or they protect investments by managing risk. Investment plays a key role in development. In the Solow Growth Model, high levels of saving (investment per worker) lead to faster output growth in the short run. Changes in the amount of capital per worker change how productive workers are an in economy. For example, Singapore had a $40 \%$ saving rate and 5-6\% GDP growth from 1960 to1996. During this same time period, Kenya had a 15\% saving rate and GDP growth of about $1 \%$.

Usually, the lesser-developed economies do not have access to financial technologies because perspective borrowers lack collateral; institutions do not want to pay high monitoring, screening, and enforcement costs; and risks are very high in populations that suffer from severe illness, malnutrition, and low levels of education.

So, we can say that MFIs give the opportunity to financial technologies to the poor. But the question is that, how much is this opportunity available for the poor? If MFIs can ensure this availability at reasonable 
condition then it will promote the economic growth and development.

\section{Why Has Microfinance Not Worked as Hoped?}

We find some reasons for underperformance of MFIs which are as follows:

- Growing dependency of upon micro-credit, coupled with high interest rates, means that a growing proportion of the unstable income of the poor is obstacle to cover interest charges.

- Unsustainable micro credit indebtedness is common place across developing countries.

- Interest rates have not fallen as much as predicted that means it was predicted that after covering high operational cost, interest rate of MFIs will be lower.

- Emphasis on the commercial model with MFIs now required generating high financial rewards for their manners (salaries, bonuses) and owners/shareholders (dividends and capital gains).

- Market saturation and displacement of developing countries tends clients of microfinance in short-term micro enterprises neglecting the long-term micro enterprises.

\section{Is Microfinance Sustainable?}

Sustainability in simple terms refers to the long-term continuation of the microfinance program after the project activities have been discontinued. It entails that appropriate systems and processes have been put in place that will enable the microfinance services to be available on a continuous basis and the clients continue to benefit from these services in a routine manner. This also would mean that the program would meet the needs of the members through resources raised on their own strength, either from among themselves or from external sources.

By their current position as well as future prospective, most MFIs are sustainable in the long run. Especially in case of Bangladesh, MFIs are more sustainable. However, this kind of sustainability is sometimes questioned in the open place.

\section{Recommendations}

We recommend some important issues to resolve the problems and challenges of microfinance institutions for better access to finance from the point of view of both institutions and the government.

\section{For the MFIs}

(1) The major factor of MFIs which hinders the poverty reduction approach is high interest rate. To reduce this rate, MFIs can try to reduce its default risk.

(2) MFIs should offer interest on savings and savings be made withdrawable.

(3) Periodical survey is necessary to assess the overall activity and progress.

(4) Identify the area where it works best.

(5) Long-term entrepreneurial attitude should be grown by training program.

(6) For the benefit of the poor, credit delivery at the doo-step should continue at a reasonable cost to clients.

(7) MFIs may take steps like rationalizing the cost of funds by accessing various sources of funds, increasing operational efficiency, involving local small NGOs, etc.

\section{For the Government}

(1) We know subsidy is not a good solution for the economic development but government should subsidize those area's MFIs which interest rate is relatively high due to high operation cost.

(2) Government should take some initiative to bring existing bank and insurance company forward to providing these services and to make a competitive market. 
(3) Both private and public partnership are needed to strengthen the microfinance institutions.

(4) Every attempt for reducing poverty will be failed if the purchasing power of the poor reduces due to unreasonable and intolerable price hike. So, government should always try to control this fundamental issue.

\section{Conclusion}

Today the role of MFIs is controversial for many reasons. From the very onset, MFIs of Bangladesh expanded in an unplanned way, without any definite policy from the government. It is observed throughout the article that in the name of poverty alleviation, the many MFIs are operating their microfinance business with irrational profits. That is, they are acting opportunistically rather than beneficially. These MFIs are not working to change the luck of the poor people; rather they are utilizing the poor people's money for their own interest and benefits. In true sense, they are the disguised helpers. Overall, the evidence for microfinance shows a limited impact on poverty alleviation. Comparatively lower interest charged on loan, deposit mobilization through voluntary savings, high interest rate paid on deposit, free skill development training facility, less bias on female member, mandatory insurance program, freedom from political intervention, rationalization of the cost of funds through multidimensional sources, and increase in operational efficiency and involvement of local small NGOs should be the major attributes of the policy of the MFIs for poverty alleviation.

\section{References}

Asian Development Bank. (1990). Informal finance: Some findings from Asia. Economics and Development Resource Centre. Retrieved from www.adb.org

Centre for Policy Dialogue. (2008). Bangladesh economy in 2007-08: An interim review of macroeconomic performance. Dhaka. Retrieved from www.cpd.org.bd

Chowdury, A. (2009). Microfinance as a poverty reduction tool-A critical assessment. Retrieved from http://www.inm.org.bd/publication.htm [Accessed on 20th January 2013]

Cull, R., Demirgüç-Kunt, A., \& Morduch, J. (2007). Financial Performance and outreach: A global analysis of leading micro banks. Contemporary Studies in Economic and Financial Analysis, 23(1).

Davis, J. B., Hands, D. W., \& Maki, U. (2007I). Is microfinance an ethical way to provide financial services to the poor (p. 572). Edward Elgar Publishing.

George. (2005). The role microfinance in economic empowerment of the youth. IOSR Journal of Business and Management (IOSR-JBM), 16(5), 2 ,Ver. I (May. 2014), e-ISSN: 2278-487X, p-ISSN: 2319-7668.

Khandker, S. R. (2005). Microfinance and poverty: Evidence using panel data from Bangladesh (English). The World Bank Economic Review, 19(2), May.

Khandker, S., \& Zaman, H. (2011). The impact of microfinance. Retrieved from http://www.thedailystar.net/newDesign/news-details.php?nid=177457 [Accessed on 20th September 2011]

Rahman, A. (1999). Micro-credit initiatives for equitable and sustainable development: Who pays? World Development, 27(1), 67-82.

Robinson, M. S. (2001). The microfinance revolution—Sustainable finance for the poor. Washington, USA: International Bank for Reconstruction and Development/The World Bank.

Storey, J. (1994). Understanding the small business sector. London: Thompson Learning.

Todd. (1996). Microfinance as an approach to development in low income countries. The Bangladesh Development Studies, 35(4), (December 2012), 87-111.

United Nations. (2006). Building inclusive financial sector for development. United Nations, New York.

Vision of Earth. (2010). How do we define poverty? Retrieved from http://www.visionofearth.org/news/how-do-we-define-poverty/ [Accessed on 20th September 2011]

Weiss, J., \& Montgomery, H. (2005). Microfinance and poverty reduction in Asia and Latin America. Oxford Development Studies, 33(3-4), 391-416. 
Weiss, J., Montgomery, H., \& Kurmanalieva, E. (2003). Microfinance and poverty reduction in Asia. In J. Wessi (Ed.), Poverty targeting in Asia (pp. 247-268). Cheltenham, UK and Northampton, MA,USA: Edward Elgar Publishing.

World Bank. (2008). Poverty assessment for Bangladesh: Creating opportunities and reducing east-wide divide, South Asia Region. Report No. 44321-BD. Retrieved from www.worldbank.org

Yunus, M. (2003). Banker to the poor: Micro-lending and the battle against world poverty. New York: Public Affairs.

Zeller, M., \& Meyer, R. L. (2002). Improving the performance of microfinance: Financial sustainability, outreach and impact. Jurnal Al-Muzara'ah, 2(2). ISSN p: 2337-6333; e: 2355-4363. 